The effects of hydraulic loading and $\mathrm{NaCl}$ concentrations on the regeneration of exhausted homoionic natural zeolite

\title{
ZHENIA MILÁN ${ }^{1}$, SILVIO MONTALVO ${ }^{2}$, CARLOS DE LAS POZAS $^{1}$, OSCAR MONROY ${ }^{1}$,
} ENRIQUE SÁNCHEZ ${ }^{3}$ and RAFAEL BORJA ${ }^{3, *}$

\author{
${ }^{1}$ Laboratorio de Microbiología Ambiental y Tratamiento de Residuales, Universidad Autónoma \\ Metropolitana, Iztapalapa. México. D.F.
}

${ }^{2}$ Dpto de Ingeniería Química, Universidad de Santiago de Chile, Santiago de Chile, Chile.

\author{
${ }^{3}$ Instituto de la Grasa (CSIC), Sevilla, Spain
}

\section{ABSTRACT}

A study of the suitable operational conditions for the regeneration of exhausted homoionic natural zeolite with ammonium was carried out. Laboratory-scale columns using $\mathrm{NaCl}$ solutions with concentrations of 2 and $4 \mathrm{~mol} / \mathrm{L}$ and hydraulic loadings of 4, 6 and 8 bed volumes per hour (BV/h) were assessed. For both $\mathrm{NaCl}$ concentrations studied, the hydraulic load of $6 \mathrm{BV} / \mathrm{h}$ showed the highest ammonia nitrogen output from the exhausted zeolite bed. Results showed that the hydraulic load $(\mathrm{BV} / \mathrm{h})$ had a greater influence on the regeneration efficiency than the

* Address correspondence to: R. Borja, Instituto de la Grasa (C.S.I.C.), Avda. Padre García Tejero, 4, 41012-Sevilla, Spain; Phone: + 3495 4689654, Fax: +34 95 4691262, E-mail: rborja@cica.es 
concentration of the regenerating solution.

Keywords: Ammonia nitrogen removal, ion exchange, exhausted homoionic zeolite, chemical regeneration.

\section{INTRODUCTION}

The intensive use of land for agriculture and animal breeding has led to an increase in the eutrophication of lakes, estuaries and rivers, and the contamination of underground water reservoirs as a result of the presence of nitrogen, phosphorus and carbon compounds. The continuous increase in the nutrient concentration in different sources of water has led to the introduction of strict regulations for the control of the disposal of nitrogen and phosphorus in different regions. ${ }^{[1-6]}$ Many wastewater treatment systems do not allow the removal and recovery of nutrients, and final effluents are disposed containing nitrogen and phosphorus compounds.

Different methods have been developed for removing ammonia nitrogen from sewage, agricultural and industrial wastes. Among the most widely used methods for removing ammonia from wastewaters are air stripping, ionic exchange and biological nitrification/denitrification. Many researchers concluded that ion exchange is a very promising technology for ammonia nitrogen removal, because of the low investment involved, the appropriateness in extreme climatic conditions (low temperature) and the small area needed for the process. ${ }^{\text {[-12] }}$

Ion exchange using different types of natural and synthetic zeolites has been widely employed for ammoniacal nitrogen removal. ${ }^{[13-16]}$ Several studies on ammoniacal nitrogen sorption capacity of natural zeolite (clinoptilolite and mordenite types) have shown values of between 4 - $20 \mathrm{mg} \mathrm{NH}_{4}{ }^{+} / \mathrm{g}$ of zeolite. ${ }^{[14,15,17-19]}$ Studies exist on the optimization of the ion 
exchange process using a natural zeolite (clinoptilolite) for ammonia removal. Approximately $50 \%$ to $60 \%$ of the total cost of the ion exchange process is determined by the chemical regeneration process of the zeolite. In general, hydraulic loads from 4 to 20 bed volumes per hour $(\mathrm{BV} / \mathrm{h})$ have been used previously to regenerate ammonium exhausted zeolite. ${ }^{[18-26]}$ However, no sound study on the influence of the operational conditions for achieving a maximum chemical regeneration of the zeolite has been reported to date.

The aim of the present work was to study the influence and interaction between the hydraulic loading $(\mathrm{BV} / \mathrm{h})$ and concentration of the backwash regeneration solution on chemical regeneration of zeolite in order to obtain the most practical and effective regeneration conditions of the zeolite for its reuse.

\section{MATERIALS AND METHODS}

\section{Homoionic Natural Zeolites}

The natural zeolite used in the experiments was obtained from the Oaxaca deposit in Mexico. The chemical composition of this zeolite was: $\mathrm{SiO}_{2}, 58.05 \% ; \mathrm{Al}_{2} \mathrm{O}_{3}, 11.94 \% ; \mathrm{Fe}_{2} \mathrm{O}_{3}, 4.36 \% ; \mathrm{MgO}$, 0.77\%; $\mathrm{CaO}, 5.94 \% ; \mathrm{Na}_{2} \mathrm{O}, 1.5 \% ; \mathrm{K}_{2} \mathrm{O}, 1.2 \%$; Ignition Wastes, $12.09 \%$. In addition, its phase composition was: Clinoptilolite, 35\%; Mordenite, 15\%; Montmorillonite, 30\%; Others (Calcite, Feldespate and Quartz): 20\%.

This zeolite was transformed into sodium homoionic zeolite by using a $1 \mathrm{M} \mathrm{NaCl}$ solution at approx. $90^{\circ} \mathrm{C}$ for $2 \mathrm{~h}$. This treatment was repeated twice to force the zeolite as far as possible into the relevant homoionic form. The samples treated in this way were washed with deionized water and subsequently dried at $50^{\circ} \mathrm{C} .^{[26,27]}$ 
The cationic composition of natural and homoionic zeolites was as follows (all amounts expressed as mg of cation per $\mathrm{g}$ of zeolite):

Natural zeolite: $\mathrm{Na}^{+}, 4.6 ; \mathrm{Ca}^{2+}, 16.0 ; \mathrm{K}^{+}, 15.6 ; \mathrm{Mg}^{2+}, 8.5$.

Homoionic zeolite: $\mathrm{Na}^{+}, 36.8 ; \mathrm{Ca}^{2+}, 2.0 ; \mathrm{K}^{+}, 11.7$.

The zeolite packed had $58 \%$ porosity and an apparent density of $0.81 \mathrm{~g} / \mathrm{mL}$. The natural zeolite had a particle size of between 1.0-2.0 mm.

\section{Load and Regeneration Solutions}

Ammoniacal influent feed was made from $0.01 \mathrm{~g} / \mathrm{L} \mathrm{NH}_{4} \mathrm{NO}_{3}$ stop solution. The average value of the ammonia concentration in the influent was $120 \mathrm{mg} / \mathrm{L}$. Regeneration solutions with concentrations of 2 and $4 \mathrm{~mol} / \mathrm{L}(\mathrm{M}) \mathrm{NaCl}$ were prepared with deionized water.

\section{Experimental Procedure}

Packed columns $20 \mathrm{~cm}$ high and with an internal diameter of $3.5 \mathrm{~cm}$ were used. They contained a total zeolite mass of $55 \mathrm{~g}$. Ammoniacal influent $\left(\mathrm{NH}_{4} \mathrm{NO}_{3}\right.$ solution) was pumped at $2 \mathrm{BV} / \mathrm{h}$ and both regeneration solutions ( 2 and $4 \mathrm{~mol} / \mathrm{L} \mathrm{NaCl}$ ) were used at flows of 4,6 and $8 \mathrm{BV} / \mathrm{h}$.

To obtain the best regeneration conditions, different load-regeneration cycles were applied in order to determine the loss of the ammonium capacity of packed homoionic zeolite. In all experiments, triplicate samples of effluents were taken each hour to determine the required parameters.

\section{Analytical Techniques}


99 Ammonia nitrogen was analyzed by selective electrode (ORION pH/ISE-meter 727). Sodium

100 concentration was determined by Atomic Absorption Spectrometry. Both determinations were

101 carried out following Standard Methods. ${ }^{[28]}$

Zeolite samples with a maximum weight of $0.5 \mathrm{~g}$ were digested in a microwave oven (CEM Corporation-MDS 2000). Afterwards, the sodium and ammonium contents of the liquid were also determined. This treatment aimed to characterize the zeolite after its regeneration.

\section{RESULTS AND DISCUSSION}

The relationship between the hydraulic loading $(\mathrm{BV} / \mathrm{h})$ and concentration or molarity of the backwash regeneration solution was determined in order to calculate the operation time needed and to obtain optimal operating conditions. Ammonium removal from zeolite as $\left(C_{o}-C_{i}\right) / C_{o}$ for both regeneration solutions ( 2 and $4 \mathrm{~mol} / \mathrm{L}$ ) applied at different hydraulic loads (BV/h) (Figs. 1 and 2, respectively), where $C_{o}$ denotes the ammonium concentration in the exhausted zeolite ( $22.51 \mathrm{mg} / \mathrm{g}$ of zeolite) and $C_{i}$ is the ammonium concentration at any time during the regeneration operation.

In the case of $2 \mathrm{~mol} / \mathrm{L} \mathrm{NaCl}$ solution and $6 \mathrm{BV} / \mathrm{h}$ of hydraulic loading, $60 \%$ regeneration was obtained at $4 \mathrm{~h}$ contact time, whereas $8 \mathrm{~h}$ of operation time was needed to obtain similar efficiency at $4 \mathrm{BV} / \mathrm{h}$. Finally, for $8 \mathrm{BV} / \mathrm{h}$ only $48 \%$ regeneration was reached after $12 \mathrm{~h}$ of operation time (Fig. 1).

For $4 \mathrm{~mol} / \mathrm{L}$ of the regenerating solution and hydraulic loading of $6 \mathrm{BV} / \mathrm{h}$ (Fig. 2), $60 \%$ regeneration was achieved in the first hour of operation and a maximum of $80 \%$ was obtained at 
$8 \mathrm{~h}$ operation time. By comparing the hydraulic loads of 4 and $8 \mathrm{BV} / \mathrm{h}$, the behaviour was only slightly different during the first five hours of operation. In both cases the systems achieved equilibrium at $9 \mathrm{~h}$ operation time with a regeneration percentage of $65 \%$. For both concentrations and similar hydraulic loadings the curves showed a tendency to reach equilibrium at between 8 and 10 hours operation time. At $4 \mathrm{~mol} / \mathrm{L}$ of regenerating solution and at $4 \mathrm{BV} / \mathrm{h}$, equilibrium was achieved at $3 \mathrm{~h}$, while at other hydraulic loadings 8 hours were needed. For all hydraulic loadings applied with $2 \mathrm{~mol} / \mathrm{L}$ concentration solutions equilibrium was obtained after $10 \mathrm{~h}$. At $4 \mathrm{~mol} / \mathrm{L}$ of regenerating solution and hydraulic loading of $4 \mathrm{BV} / \mathrm{h}$, equilibrium was achieved before of comparing to 6 and $8 \mathrm{BV} / \mathrm{h}$ regeneration curves.

Lower concentrations of the regenerating solutions $(0.5 \mathrm{~mol} / \mathrm{L}, \mathrm{NaCl})$ and higher flow-rates of these solutions (15-20 BV/h) were previously used to reduce ammonia concentration in regeneration solution effluent to below $0.5 \mathrm{mg} \mathrm{NH}_{4}{ }^{+}-\mathrm{N} / \mathrm{L} .{ }^{[18]}$ Low concentration of the regenerating solution $\left(0.1 \mathrm{mg} / \mathrm{L}, \mathrm{NaHCO}_{3}\right)$ was also used during the desorption of uranium (VI) in fixed bed ion-exchange columns using natural zeolite coated with Manganese oxide (MOCZ). The column could be used for at least four adsorption-desorption cycles using the abovementioned $\mathrm{NaHCO}_{3}$ solution concentration. ${ }^{[29]}$ Loadings of 7-8 BV/h of a regenerating solution of $\mathrm{NaCl}$ were also used for eliminating more than $95 \%$ of adsorbed ammonium ions in benchscale packed zeolite columns. The adsorption-regeneration time ratio was approximately $5: 1 .^{[30]}$ In all systems studied in the present work, the first two-hour operation appears to have a great influence on the overall kinetics since the relationships between sodium and ammonium concentrations in the liquid-solid interface are the highest. In order to demonstrate this, a mass balance for determining the leached ammonium for hydraulic loadings of 6 and $8 \mathrm{BV} / \mathrm{h}$ was carried out with a regenerating solution concentration of $4 \mathrm{~mol} / \mathrm{L}$. Figure 3 presents the variation of the accumulative ammonium concentration leached in this experiment with the operation time; 
different responses were observed during the first $30 \mathrm{~min}$. A higher concentration of ammonium in the leachate was found in the effluent solution obtained at $6 \mathrm{BV} / \mathrm{h}$ than at $8 \mathrm{BV} / \mathrm{h}$. At 1.5 hours of operation time the leachate concentrations were $0.9 \mathrm{mg} / \mathrm{L}$ and $0.7 \mathrm{mg} / \mathrm{L}$ for 6 and $8 \mathrm{BV} / \mathrm{h}$, respectively, indicating an influence of liquid velocity only during the first hour of operation time. This behaviour could be determined by the fact that at $8 \mathrm{BV} / \mathrm{h}$ the diffusion in zeolite structure could be affected by a higher linear velocity applied to the system. Diffusion may be the controlling step in this process, and consequently further ionic exchange sites to solid-liquid interface could not be reached. ${ }^{[19,31-35]}$ Overall rates of adsorption, desorption and ion exchange in porous materials are generally controlled by mass transport within the pore network, rather than by the kinetics of desorption or ion exchange itself. ${ }^{[32]}$ Actually, the effective diffusion coefficient is a macroscopic average over a large number of ions (or molecules) in pores of different sizes, shapes and directions and at larger and smaller distances from the pore walls, expressing the average ability of the species to make headway in any given direction. Limited data are also available on the rates of some metal exchanges on zeolite, in terms of diffusion coefficients. $^{[32]}$

Based on the results obtained in the present work, the values of the diffusion coefficients were determined for all conditions studied according to the model described previously by Roque. $^{[31]}$ These values were summarized in Table 1 . For a same hydraulic loading, the diffusion coefficient corresponding to the lowest $\mathrm{NaCl}$ concentration (2M) was always higher than that corresponding to the highest concentration used (4 M), especially in the case of a hydraulic load of $4 \mathrm{BV} / \mathrm{h}$.

The values of the diffusion coefficients obtained in this work were somewhat higher than those obtained in the lead uptake process by using clinoptilolite with particle sizes in the range of $0.02-0.045 \mathrm{~cm} .^{[31]}$ 
Table 2 summarizes the zeolite characteristics after the regeneration step. The sodium concentration in the zeolite increased with the concentration of regenerating solution. Analyzing the load effect at the same concentration of regenerating solution, it was observed that operating the systems at $6 \mathrm{BV} / \mathrm{h}$ only half the time is needed to reach $60 \%$ removal as compared to $4 \mathrm{BV} / \mathrm{h}$, while at $8 \mathrm{BV} / \mathrm{h}$ the required operation time was more than three times higher. As a consequence, the required $\mathrm{NaCl}$ consumption was higher as the operation time increased.

When the systems were fed with $4 \mathrm{M}$ solutions the operation times were shorter and the regeneration efficiencies were maximized, but this also implies an economic analysis. Based on the last results, different load-regeneration cycles were carried out at $6 \mathrm{BV} / \mathrm{h}$ hydraulic loading, for both $\mathrm{NaCl}$ concentrations. Figure 4 shows the cyclic behaviour of nitrogen and sodium content in the packed zeolite column between each load (with an ammonium solution of 120 $\mathrm{mg} / \mathrm{L}$ - impair)-regeneration (with both $\mathrm{NaCl}$ solutions - pair) cycle.

Despite the cyclic behaviour shown, the ion concentration in the zeolite denotes a slight diminution of both sodium and ammonium between each cycle (load-regeneration). From the second regeneration cycle the breakthrough load point was two hours lower than the first ammonium load, and for the third and fourth cycles four and six hours lower, respectively. This could be due to zeolite loss caused by mechanical shut-down forces and to the $\mathrm{pH}$ and conductivity values of regenerating solutions. This phenomenon was also previously observed during a study of regeneration step optimization, ${ }^{[23]}$ which implied the substitution of $5 \%$ zeolite mass column between four and six months, depending on the regeneration step frequency.

Effluent regenerating analysis showed sodium concentration values of $44 \pm 3$ and $84 \pm 2 \mathrm{~g} / \mathrm{L}$, for 2 and $4 \mathrm{M}$ respectively, from the fourth-hour of operation time. In the case of ammonium, the values were lower than 85 and $72 \mathrm{mg} / \mathrm{L}$, for 2 and $4 \mathrm{M} \mathrm{NaCl}$ solutions respectively. Then, taking into account the ammonium quantity in the regenerating solution output it is possible to suggest 
194 the recirculation of regenerating effluent from a fourth-hour operation time. Besides, it is also

195 necessary to find a sustainable alternative for disposing of this high ammonium content effluent,

196 according to the geographical location where the technology is being applied.

\section{CONCLUSIONS}

A higher influence of the hydraulic loading of the regeneration solution than of the concentration of this solution on the regeneration efficiency was found. For a hydraulic loading of $8 \mathrm{BV} / \mathrm{h}$ a considerable diminution in the regeneration efficiency was observed. The cyclic behaviour of different load-regeneration showed a slight progressive decrease in the zeolite capacity. Therefore, it is very important to consider putting back the material of exchange due to the capacity lost during the process.

\section{REFERENCES}

[1] Fai, G.; Geyer, J.; Okun, D. Purificación de aguas y tratamiento y remoción de aguas residuales. Ingeniería Sanitaria y de Aguas Residuales Vol. 2, Primera parte. $4^{\text {th }}$ ed, 1987, pp. $217-273$.

[2] Hobson, P.N.; Robertson, A.M. Waste treatment in Agriculture, Applied Science Publishers, London, 1977.

[3] Taiganides, E.D. Animal Wastes, Elsevier, London, 1977.

[4] Gomes-Ferreira, J.; Bricker, S.B.; Castro-Simas, T. Application and sensitivity testing of an eutrophication assessment method on coastal systems in the United States and European Union. J. Environ. Manage. 2007, 82, 433-445. 
[5] Mao, J.; Chen, O.; Chen, Y. Three dimensional eutrophication model and application to Taihu Lake, China. J. Environ. Sci. 2008, 20, 278-284.

[6] Kotta, J.; Kotta, I.; Sunm, M.; Pollupüü, M. Separate and interactive effects of eutrophication and climate variables on the ecosystem elements of the Gulf of Riga, Estuarine. Coast Shelf Sci. 2009, 84, 509-518.

[7] Panayotova, M.; Velikov, B. Influence of zeolite transformation in a homoionic form on the renoval of some heavy metal ions from wastewater J. Environ. Sci. Health part A., 2003, 38, 545-554.

[8] Armagan, B. Factors affecting the performances of sepiolite and zeolite for the treatment of textile wastewater. J. Environ. Sci. Health part A., 2003, 38, 883-896.

[9] Tobinaga, T.; Shoji, R. Development of new toxicity identification evaluation by assessing toxicity reduction on adsorption and ion-exchange treatments. J. Environ. Sci. Health part A., 2004, 39, 2341-2353.

[10] Wajima, T.; Shimizu, T.; Ikegami, Y. Synthesis of zeolites from paper sludge ash and their ability to simultaneously remove $\mathrm{NH}_{4}{ }^{+}$and $\mathrm{PO}_{4}{ }^{3-}$. J. Environ. Sci. Health part A., 2007, 42, 345-350

[11] Milán, Z.; Montalvo, S.; Ruiz-Nagle, N.; Urrutia, H.; Chamy, R.; Sánchez, E.; Borja, R. Influence of heavy metal supplementation on specific methanogenic activity and microbial communities detected in batch anaerobic digesters. J. Environ. Sci. Health part A., 2010, 45, 1307-1314.

[12] Milan, Z.; Montalvo, S.; Ilangovan, K.; Monroy, O.; Chamy, R.; Weiland, P.; Sánchez, E.; Borja, R. The impact of ammonia nitrogen concentration and zeolite addition on the specific methanogenic activity of granular and flocculent anaerobic sludges. J. Environ. Sci. Health part A., 2010, 45, 883-889. 
[13] Rožić, M.; Cerjan-Stefanovič, S.; Kurajica, S.; Vančina, V.; Hodž, E. Ammoniacal nitrogen removal from water by treatment with clays and zeolites. Water Res. 2000, 34, 3675-3681.

[14] Sanchez, E.; Milan, Z.; Borja, R.; Weiland, P. Piggery waste treatment and nutrient removal by ionic exchange. Resour. Conserv. Recyc. 2005, 15, 235-244.

[15] Jung, J.Y.; Chung, Y.C.; Shin, H.S.; Son, D.H. Enhanced ammonia nitrogen removal using consistent biological regeneration and ammonium exchange of zeolite in modified SBR process. Water Res. 2004, 38, 347-354.

[16] Karapma, N. Application of natural zeolite for phosphorus and ammonium removal from aqueous solutions. J. Hazard. Mater. 2009, 170, 1186-1191.

[17] Booker, N.A.; Cooney, E.L.; Priestley, A.J. Ammonia removal from sewage using natural Australian zeolite. Water Sci. Technol. 1996, 34, 17-24.

[18] Du, Q.; Liu, Z.; Cao, Z.; Wang, Y. Ammonia removal from aqueous solution using natural Chinese clinoptilolite. Sep. Purif. Technol. 2005, 44, 229-234.

[19] Cooney, E.L.; Booker, N.A.; Shallcross, D.C.; Stevens, G.W. Ammonia removal from wastewaters using natural Australian zeolite. I. Characterization of the zeolite. Sep. Sci. Technol. 1999, 34, 2307-2317.

[20] Amplhet, C.B. Inorganic Ion Exchanger: The Zeolites. Elsevier, New York, 1964.

[21] Ames, L.L. Zeolitic removal of ammonium ions from agricultural and other wastewater. $13^{\text {th }}$ Pacific Northwest Industrial Waste Conference Proceeding, Washington State University, Pullman, 1967.

[22] Mercer, B.W.; Arnett, R.C.; Dean, R.B. Optimization of column performance for ammonia removal from wastewater using selective ion exchange. Wastewater Reclamation and Reuse Workshop Proceedings, Sanitary 
Engineering Research Laboratory, University of California, Berkeley, 1970, pp. 25-27.

[23] USEPA, Optimization of ammonia removal by ion exchange using clinoptilolite. Project No. 17080 DAR. Water Pollution Control Research Series, Berkeley, California, USA, 1971.

[24] Koon, J.H.; Kaufman, W.J. Ammonia removal from municipal wastewater by ion exchange. J. Water Poll. Control Fed. 1975, 47, 448-467.

[25] Semmens, M.J.; Wang, J.T.; Booth, A.C. Nitrogen removal by ion exchange: biological regeneration of clinoptilolite. J. Water Poll. Control Fed. 1977, 49, 2431-2444.

[26] Milán, Z.; Sánchez, E.; Weiland, P.; De las Pozas, C.; Borja, R.; Mayari, R.; Rovirosa, N. Ammonia removal from anaerobically treated piggery manure by ion exchange in columns packed with homoionic zeolite. Chem. Eng. J. 1997, 66, 6571.

[27] Jama, M.A.; Yucel, H. Equilibrium studies of sodium-ammonium, potassium-ammonium and calcium-ammonium exchanges on clinoptilolite zeolite. Sep. Sci. Technol. 1990, 24, 1393-1416.

[28] APHA-AWWA-WPCF. Standard Methods for the Examination of Water and Wastewater, 17th edition (American Public Health Association), Washington, 1989.

[29] Zou, W.; Zhao, L.; Han, P. Removal of uranium (VI) by fixed bed ion-exchange column using natural zeolite coated with Manganese oxide. Chinese J. Chem. Eng. 2009, $17,585-593$.

[30] Liu, C.H.; Lo, K.V. Ammonia removal from compost leachate using zeolite III. 
Regeneration of zeolite columns. J. Environ. Sci. Health A 2001, 36, 1825-1843.

291 [31] Roque, R. Física química de las zeolitas. CNIC, Editorial Pueblo y Educación, 1st. Edition. C. Habana, Cuba, 1988.

[32] Inglezakis, V.J.; Diamandis, N.A.; Loizidou, M.D.; Grigoropoulu, H.P.

[33] Inglezakis, V.J.; Loizidou, M.D.; Grigoropoulu, H.P. Equilibrium and kinetic ion exchange studies of $\mathrm{Pb}^{2+}, \mathrm{Cr}^{3+}, \mathrm{Fe}^{3+}$ and $\mathrm{Cu}^{2+}$ on natural clinoptilolite. Water Res. 2002, 36, 2784-2792.

[34] Dyer, A.; White, K.J. Cation diffusion in the natural zeolite clinoptilolite. Thermochim. Acta 1999, 340, 341-348.

[35] Karger, J. Measurement of diffusion in zeolites - A never ending challenge. Adsorption 2003, 9, 29-35.

(n)

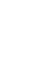

(n)

\section{.}




\section{FIGURE CAPTIONS}

Figure 1. Time course of zeolite regeneration using a $2 \mathrm{~mol} \mathrm{NaCl} / \mathrm{L}$ solution with different loads $321(\mathrm{BV} / \mathrm{h})$.

Figure 2. Time course of zeolite regeneration using a $4 \mathrm{~mol} \mathrm{NaCl} / \mathrm{L}$ solution with different loads $(\mathrm{BV} / \mathrm{h})$.

Figure 3. Accumulative ammonium concentration leached at hydraulic loadings of 6 and $8 \mathrm{BV} / \mathrm{h}$.

Figure 4. Variation of the amount of ammonium and sodium chloride exchanged in 


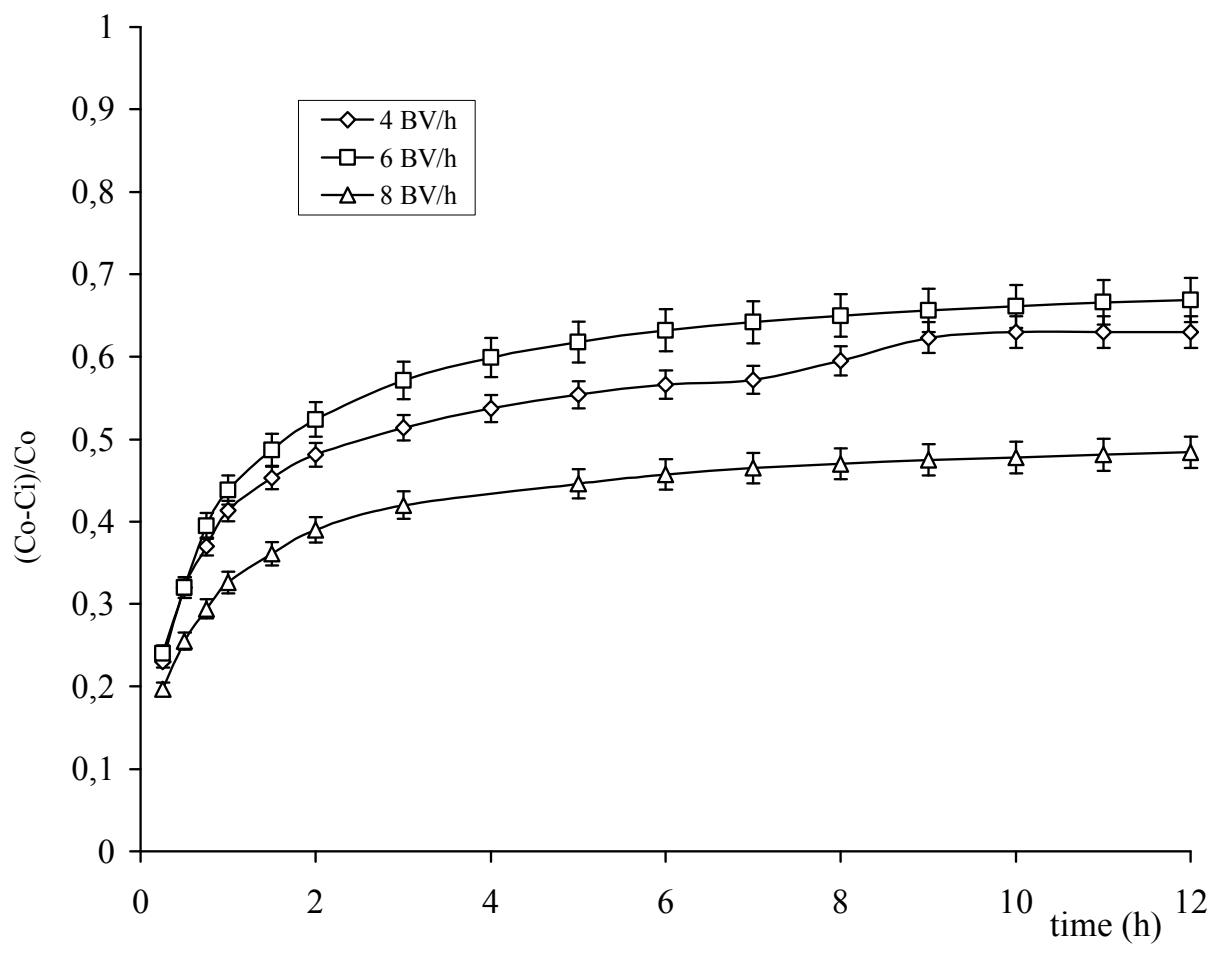

Fig. 1 


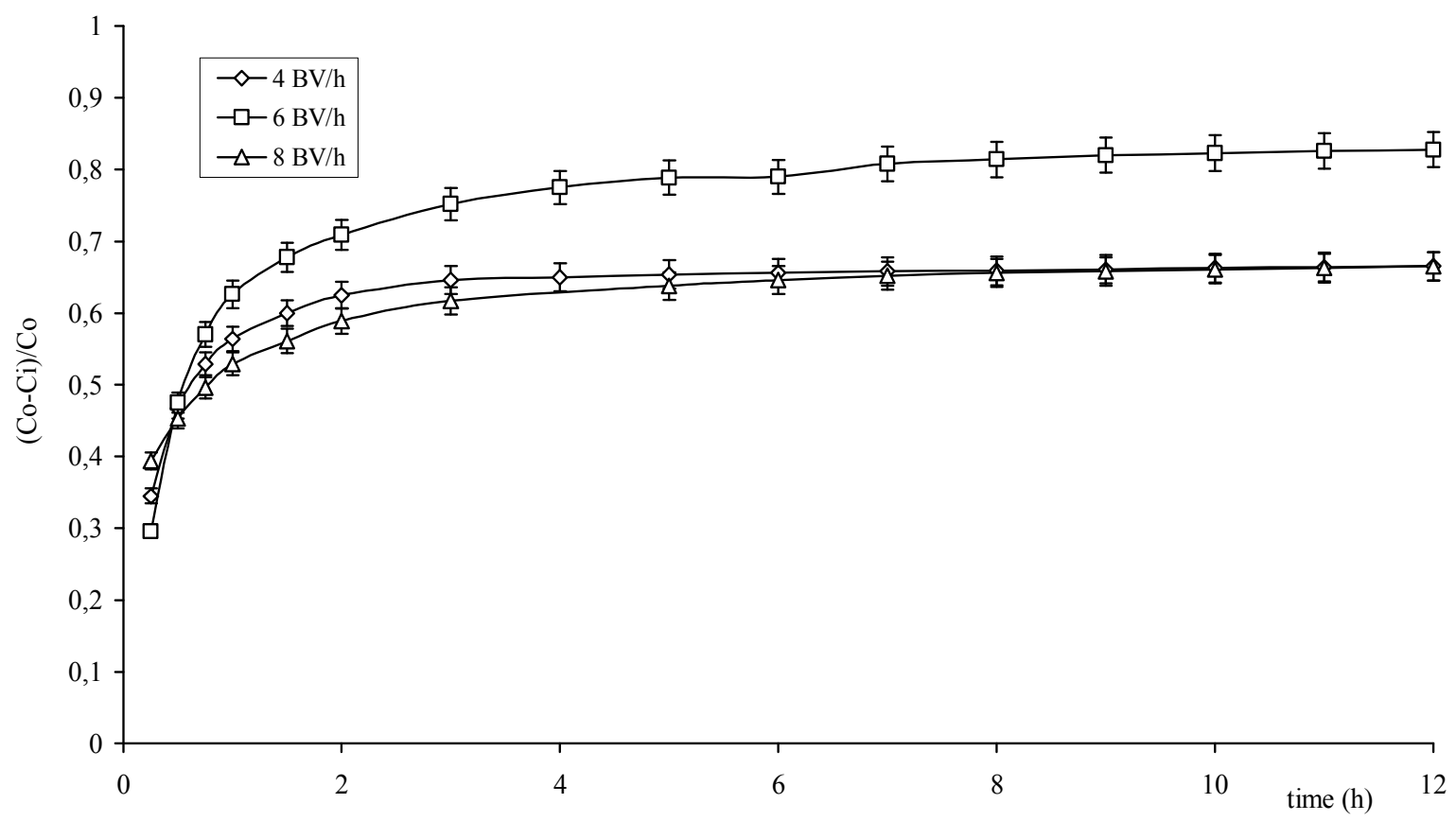

Fig. 2

371

372

373

374

375

376

377

378

379

380

381

382

383

384

385

386

387

388 


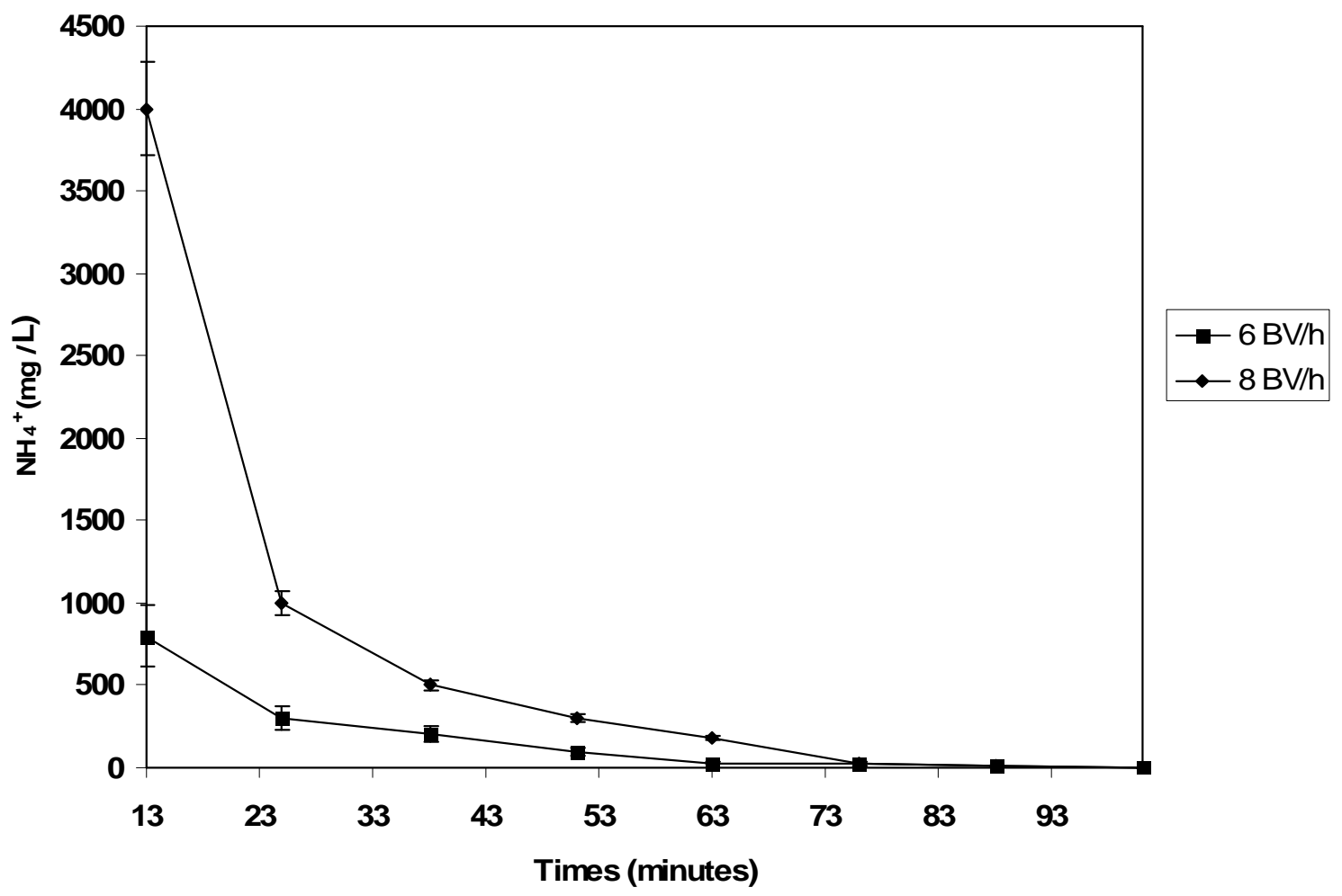

Fig. 3

392

393

394

395

396

397

398

399

400

401

402

403

404

405

406

407

408 


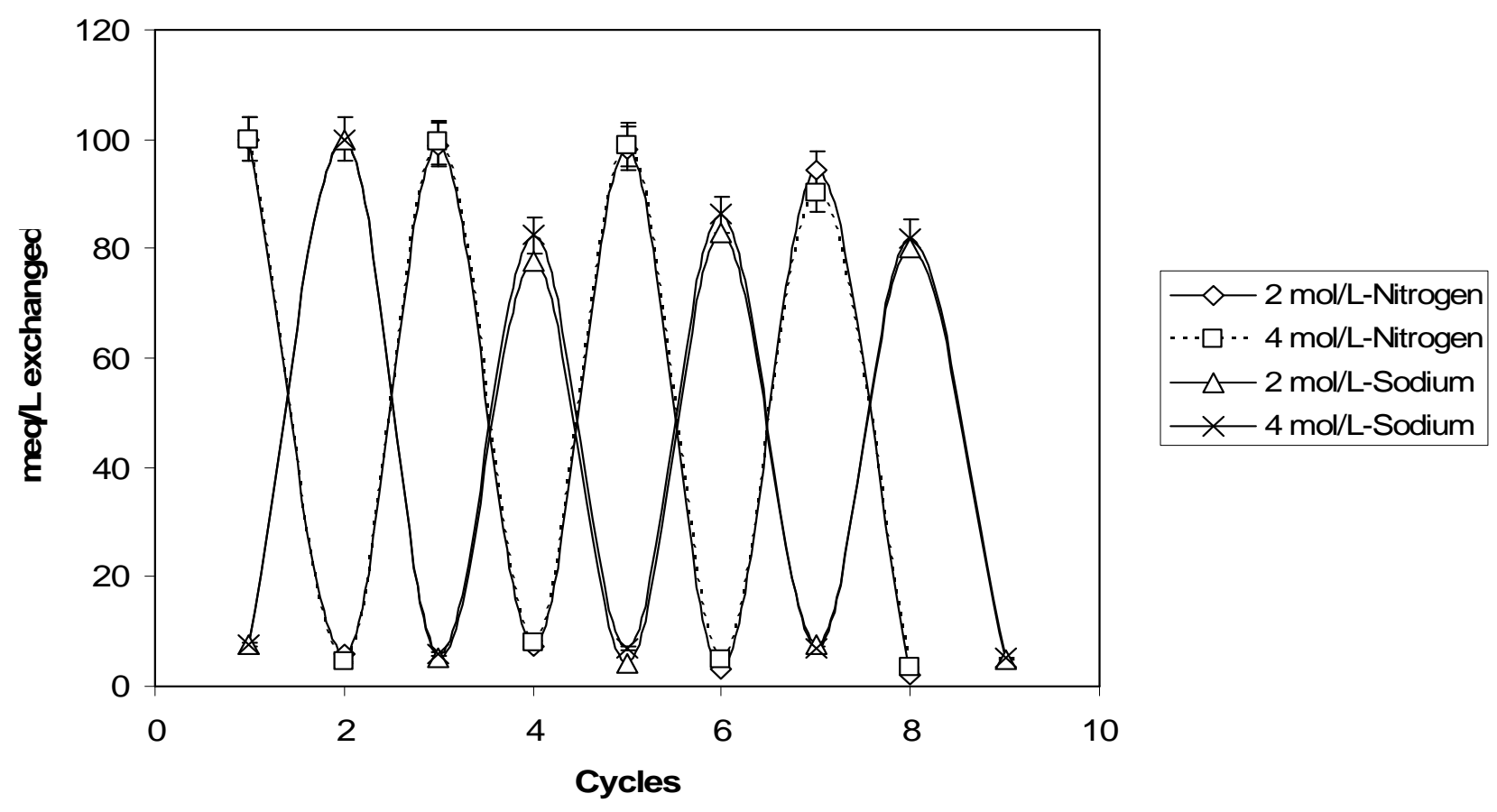

410

411 Fig. 4

412

413

414

415

416

417

418

419

420

421

422

423

424

425

426

427

428 
430 Table 1. Values of the diffusion coefficients $\left(D e, \mathrm{~cm}^{2} / \mathrm{s}\right) *$ obtained for all the experimental 431 conditions tested. cases.

\begin{tabular}{ll} 
conditions (Load & $\left(\mathrm{cm}^{2} / \mathrm{s}\right)$ \\
and $\mathrm{NaCl}$ conc. $)$ & \\
\hline 4BV/h and $2 \mathrm{~mol} / \mathrm{L}$ & $4.5 \times 10^{-8}$ \\
4BV/h and $4 \mathrm{~mol} / \mathrm{L}$ & $0.6 \times 10^{-8}$ \\
6BV/h and $2 \mathrm{~mol} / \mathrm{L}$ & $2.9 \times 10^{-8}$ \\
$6 \mathrm{BV} / \mathrm{h}$ and $4 \mathrm{~mol} / \mathrm{L}$ & $2.3 \times 10^{-8}$ \\
\hline $8 \mathrm{BV} / \mathrm{h}$ and $2 \mathrm{~mol} / \mathrm{L}$ & $2.4 \times 10^{-8}$ \\
\hline $\mathrm{BV} / \mathrm{h}$ and $4 \mathrm{~mol} / \mathrm{L}$ & $1.8 \times 10^{-8}$
\end{tabular}


445 Table 2. Results of the zeolite features after its regeneration.

\begin{tabular}{lllll}
\hline Condition (Load & $\begin{array}{l}\mathrm{mg} \text { of } \mathrm{Na}^{+} / \mathrm{g} \\
\text { and NaCl conc.) }\end{array}$ & $\begin{array}{l}\text { Breakthrought } \\
\text { of zeolite \& }\end{array}$ & $\begin{array}{l}\mathrm{t}_{60 \%}(\mathrm{~h}) \& \& \\
\text { removal percent }\end{array}$ & $\begin{array}{l}\text { Required } \mathrm{g} \\
\left.\text { of }^{\mathrm{Na}}{ }^{*}\right)\end{array}$ \\
4BV/h and 2 mol/L & 33.09 & 60 & 8 & 88.73 \\
4BV/h and 4 mol/L & 34.55 & 60 & 1.5 & 35.04 \\
6BV/h and 2 mol/L & 31.73 & 60 & 4 & 74.89 \\
6BV/h and 4 mol/L & 34.01 & 60 & 0.88 & 28.48 \\
8BV/h and 2 mol/L & 29.76 & $50(* *)$ & $15(* *)$ & 374.03 \\
8BV/h and 4 mol/L & 33.66 & 60 & 3 & 150.7
\end{tabular}

$446 \quad(*)$ Based on $60 \%$ removal of ammonia nitrogen from zeolite bed.

$447 \quad(* *)$ Obtained from curve extrapolation.

$448 \&$ Values of sodium concentration in the zeolite were averages of three determinations; the

449 standard deviations of the mean values were less than $5 \%$ in all cases.

$450 \& \& \mathrm{t}_{60 \%}$ : time $(\mathrm{h})$ that is necessary to reach $60 \%$ ammonium removal or $60 \%$ zeolite

451 regeneration. 